\title{
PERGESERAN KEKUASAAN PRESIDEN DAN PENGUATAN KEKUASAAN DPR PASCA PERUBAHAN UUD NRI 1945
}

\author{
Mugeni \\ Mahasiswa Program Doktor Ilmu Hukum \\ Universitas Jayabaya, Jakarta \\ Korespondensi: mugeni02@yahoo.com
}

\begin{abstract}
Abstrak
Praktik penyelenggaraan pemerintahan negara yang dilaksanakan oleh Presiden selama rezim Orde Lama dan Orde Baru telah menimbulkan gelombang tuntutan kepada MPR RI pada masa reformasi agar melakukan berbagai perbaikan terhadap UUD NRI 1945. Perubahan UUD NRI 1945 yang dilakukan sejak 1999-2002, telah berhasil mendistribusi kekuasaan eksekutif, kekuasaan legislatif, dan kekuasaan yudikatif kearah suatu keseimbangan baru yang lebih proporsional ketimbang pada rezim Orde Lama dan Orde Baru. Namun jika dicermati lebih jauh, pembagian kekuasaan antara Presiden dan DPR masih tidak seimbang dan cenderung tidak hanya melampaui paradigma check and balances tetapi telah menjadi excessive. DPR tidak hanya menjalankan fungsi legislatif murni, tetapi juga melaksanakan sejumlah fungsi administrasi negara yang semestinya murni menjadi ranah kekuasaan Presiden.
\end{abstract}

Kata kunci: Perubahan UUD 1945; Presiden; DPR; Check and Balances.

\begin{abstract}
Governance practices implemented by the President during the Old Order and New Order has provoked a wave of demands to the People's Consultative Assembly in the reformation era to carry out various improvements to the Constitution of the Republic Indonesia of 1945. The amendments to the Constitution since 1999 to 2002 has been successfully distributing powers among the executive, the legislative, and the judiciary towards a new equilibrium that is more proportional than in the Old Order and New Order. But on a closer examination, the division of powers between the President and Parliament are still not balanced and tend to not only go beyond the paradigm of checks and balances but has become excessive. In fact, the Parliament does not only perform purely legislative functions, but also carries out a number of functions that should be purely within the realm of presidential powers.
\end{abstract}

Key Words: Amendment of the 1945 Constitution; President; Parliament; Checks and Balances. 


\section{PENDAHULUAN}

Runtuhnya rezim Orde Baru tahun 1997 seiring dengan lengsernya Presiden Soeharto, telah memunculkan era yang berusaha mereformasi tatakelola penyelengaraan pemerintahan negara, antara lain memperbaiki dan memperbarui sistem ketatanegaraan yang mengandung banyak kelemahan dalam penyelenggaraan pemerintahan pada era sebelumnya. Reformasi terhadap kehidupan ketatanegaraan itu antara lain dilakukan dengan merubah beberapa ketentuan dalam UndangUndang Dasar Negara Republik Indonesia Tahun 1945 (UUD NRI 1945) yang dinilai mengandung kelemahan dalam rangka menata kehidupan kenegaraan modern yang lebih baik. Dalam kurun waktu 4 (empat) tahun usia reformasi, MPR RI telah berhasil merubah ketentuan dalam UUD NRI 1945 sebanyak 4 (empat) kali. Perubahan itu dilakukan masing-masing pada tahun 1999, 2000, 2001, dan 2002.

Tuntutan perubahan terhadap UUD NRI 1945 muncul sedemikian rupa karena penilaian berdasarkan pengalaman praktik ketatanegaraan di era pemerintahan sebelumnya, bahwa kekuasaan presiden tampil begitu dominan dalam penyelenggaraan pemerintahan negara dibanding dengan kekuasaan lain seperti kekuasaan legislatif dan kekuasaan yudisial. Begitu juga kontrol terhadap pemerintahan yang lemah atau ketiadaan mekanisme checks and balances yang kuat. Untuk sedikit menggambarkan begitu kokohnya kekuasaan Presiden pada masa Orde Baru, Valina Singka Subekti menulis sebagai berikut:

Kekuasaan Soeharto telah
membelenggu suara rakyat, serta
mengecilkan peran berbagai lembaga
demokrasi seperti partai politik,
pemilihan umum, DPR, dan MPR
sehingga lembaga-lembaga politik
menjadi tidak mampu melakukan
tugasnya, yaitu memperjuangkan
aspirasi yang diwakilinya. Partai politik
tidak berperan, DPR lemah berhadapan
dengan eksekutif sehingga eksekutif
tidak terawasi dengan baik.

Praktik-praktik penyelenggaraan pemerintahan yang dilaksanakan oleh presiden selama masa Orde Baru yang tidak demokratis sebagaimana digambarkan sebelumnya yang kemudian telah menimbulkan tuntutan yang kuat kepada MPR agar merubah UUD NRI 1945, khususnya terhadap pasal-pasal yang berhubungan dengan kekuasaan presiden. Isu sentral perubahan UUD NRI 1945 pada awal reformasi adalah pembatasan kekuasaan presiden dan memperkuat peran DPR. Perubahan UUD NRI 1945 yang pada masa Orde Baru tidak tersentuh karena sangat sulit dilakukan, maka perubahan yang sudah mencapai 4 (empat) kali pada masa reformasi itu, seperti memenuhi syahwat para politisi dan banyak pakar hukum ketatanegaraan, termasuk para akademisi yang sejak lama menginginkan adanya perubahan.

Valina Singka Subekti, Menyusun Konstitusi Transisi: Pergulatan Kepentingan dan Pemikiran dalam Proses Perubahan UUD 1945 (Rajawali Pers 2008) 187. 
Sebenarnya perubahan UUD suatu negara adalah keniscayaan. Dalam konteks ini Sri Soemantri mengemukakan beberapa alasan berikut. Pertama, generasi yang hidup sekarang tidak dapat mengikat generasi yang akan datang. Kedua, hukum konstitusi hanya salah satu bagian dari hukum tata negara. Ketiga, ketentuanketentuan undang-undang dasar selalu dapat diubah. ${ }^{2}$

Selain menurut teorinya bahwa setiap konstitusi suatu negara itu memang dapat diubah untuk menyesuaikan dengan perkembangan ketatanegaraan yang terjadi di masingmasing negara, juga karena dalam konteks Indonesia, UUD NRI 1945 itu sendiri telah memberikan kewenangan secara terbuka untuk diubah dan disesuaikan dengan kebutuhan rakyat dan perkembangan ketatanegaraan yang terjadi. Dalam Pasal 37 UUD NRI 1945 (sebelum perubahan) ditegaskan:

(1) Untuk mengubah Undang-Undang Dasar sekurang-kurangnya 2/3 dari pada jumlah anggota Majelis Permusyawaaratan Rakyat harus hadir.

(2) Putusan diambil dengan persetujuan sekurang-kurangnya $2 / 3$ daripada jumlah peserta yang hadir.

Selain itu memang UUD NRI 1945 yang disahkan pada tanggal 18 Agustus 1945 oleh Panitia Persiapan Kemerdekaan Indonesia (PPKI) hanyalah sebuah Undang-Undang Dasar sementara yang masih harus disempurnakan. Presiden Soekarno sendiri mengistilahkan UUD NRI 1945 sebagai suatu revolutie grondwet atau Undang-Undang Dasar kilat, yang memang harus diganti dengan yang baru apabila negara merdeka sudah berdiri dan keadaan sudah memungkinkan. Selain itu sifat sementaranya memang ditegaskan sendiri oleh Ketentuan Tambahan Pasal II UUD NRI 1945 yang berbunyi: "Dalam enam bulan sesudah Majelis Permusyawaratan Rakyat terbentuk, Majelis ini bersidang untuk menetapkan Undang-Undang Dasar." Kemudian pada Pasal 37 UUD NRI 1945 juga sudah diatur tentang mekanisme untuk melakukan perubahan terhadap UUD NRI 1945 itu sendiri.

Selain beberapa alasan sebelumnya, setelah dikaji secara akademis ataupun dari praktik ketatanegaraan yang terjadi selama UUD NRI 1945 itu berlaku, ternyata mengandung banyak kelemahan mendasar yang mengganggu jalannya pemerintahan yang demokratis atau pun jalannya negara hukum Indonesia. Moh. Mahfud MD mengupas empat kelemahan UUD NRI 1945. Pertama, UUD NRI 1945 membangun sistem politik yang memberikan kekuasaan sangat besar kepada Presiden (executive heavy) sehingga Presiden menjadi steril dari kekuatan kontrol dan penyeimbang kekuatan dari luar karena tidak ada mekanisme checks and balances yang ketat. Kedua, lembaga legislatif (yang secara praktis didominasi oleh Presiden) memiliki

$2 \quad$ Sri Soemantri, Prosedur dan Sistem Perubahan Konstitusi (PT. Alumni 2006) 272-273. 
atribusi dan delegasi kewenangan yang sangat besar untuk menafsirkan lagi hal-hal penting yang ada dalam UUD NRI 1945 dengan peraturan pelaksanaan atau undang-undang organik. Oleh karena kekuasaan Presiden sangat besar maka implementasi atribusi dan delegasi kewenangan itu sangat ditentukan oleh kehendak Presiden yang cenderung menimbun kekuasaan secara terus menerus. Ketiga, UUD NRI 1945 memuat pasal-pasal tentang kekuasaan yang ambigu (multitafsir) yang dalam praktiknya tafsir yang dibuat oleh Presiden sajalah yang harus diterima sebagai tafsir yang benar dan mengikat. Keempat, UUD NRI 1945 terlalu menggantungkan kepada semangat orang dengan pernyataan bahwa semangat penyelenggara negaralah yang akan menentukan baik buruknya negara ini. Padahal penyelenggara (penguasa) itu cenderung korup dan akan benar-benar korup jika tidak diletakkan di dalam sistem aturan main yang ketat membatasi kekuasaannya. ${ }^{3}$

Selain itu dikemukakan pula oleh A. Mukthie Fadjar beberapa alasan perlunya perubahan terhadap UUD NRI 1945, yaitu alasan historis, alasan filosofis, alasan teoretis, alasan yuridis dan alasan politis. Berdasarkan alasan historis, pembentukan UUD NRI 1945 didesain oleh pendiri negara sebagai UUD yang bersifat sementara. Alasan filosofis karena UUD NRI 1945 telah mencampuradukkan gagasan yang saling bertentangan seperti: paham kedaulatan rakyat dengan paham integralistik, paham negara hukum dengan negara kekuasaan. Alasan teoritis, dari sudut pandang teori konstitusi keberadaan konstitusi dalam suatu negara hakikatnya adalah untuk kekuasaan agar tidak sewenangwenang, namun ternyata UUD NRI 1945 lebih menonjolkan pengintegrasian. Alasan yuridis, konstitusi tertulis memuat klausula perubahan di dalamnya seperti yang termuat dalam Pasal 37. Sedangkan alasan politis, karena di dalam praktik bernegara sering mengalami perubahan yang menyimpang dari teks aslinya. ${ }^{4}$

Memang lazimnya yang berlaku di berbagai negara, setiap konstitusi yang tertulis mencantumkan pasal tentang perubahan. Hal ini disebabkan karena suatu konstitusi, walaupun ia dirancang untuk jangka waktu yang lama, selalu akan tertinggal dari perkembangan masyarakat, sehingga pada suatu saat kemungkinan perkembangan itu terjadi, maka konstitusi itu perlu diubah. ${ }^{5} \mathrm{Di}$ samping itu seperti yang dikemukakan oleh Jimly Asshiddiqie, setiap kurun waktu sejarah memberikan pula kondisikondisi kehidupan yang membentuk dan mempengaruhi kerangka pemikiran (frame of reference) dan medan pengalaman (field of experience) dengan muatan kepentingan yang berbeda, sehingga proses pemahaman terhadap

Sri Soemantri dan Moh. Mahfud MD, Amandemen UUD 1945: Antara Teks dan Konteks dalam Negara yang Sedang Berubah (Sinar Grafika, 2000) 12.

4 Sulardi, Reformasi Hukum-Rekonstruksi Kedaulatan Rakyat dalam Membangun Demokrasi (InTRANS Publishing 2009) 29. 
suatu ketentuan Undang-Undang Dasar dapat terus berkembang dalam praktek kemudian hari. ${ }^{6}$ Dalam konteks inilah maka harus dipahami, bahwa Perubahan UUD NRI 1945 merupakan satu kesatuan rangkaian perumusan hukum dasar Indonesia di masa depan. Isinya mencakup dasar-dasar normatif yang berfungsi sebagai sarana pengendali (tool of social and political control), terhadap penyimpangan dan penyelewengan dalam dinamika perkembangan zaman dan sekaligus sebagai sarana pembaruan masyarakat (tool of social and political reform) serta sarana perekayasaan (tool of social and poltical engeneering). ${ }^{7}$

Dari apa yang disampaikan di atas sudah cukup untuk menjelaskan, bahwa suatu undang-undang dasar itu sangat dipengaruhi oleh dimensi ruang dan waktu atau sangat tergantung dengan kesesuaian dan tuntutan zaman. Konstitusi sebagai produk politik sekaligus produk hukum oleh suatu generasi, sepatutnya segera direformasi manakala substansinya sudah tidak sesuai dengan perkembangan zaman dan tuntutan reformasi generasi berikutnya. $^{8}$

Secara umum tujuan dilakukannya amandemen terhadap suatu undangundang dasar adalah:

a. Mengubah, menambah, mengurangi, atau memperbarui redaksi dan substansi konstitusi (sebagian atau seluruhnya), supaya sesuai dengan kondisi ideologi, politik, ekonomi, sosial, budaya, serta kondisi pertahanan dan keamanan bangsa pada zamannya.

b. Menjadikan UUD sebagai norma perjuangan demokrasi bangsa yang terus bergulir untuk mengembalikan paham konstitusionalisme, sehingga jaminan dan perlindungan hak asasi manusia dapat ditegakkan, anatomi kekuasaan tunduk pada hukum atau tampilnya supremasi hukum, dan terciptanya peradilan yang bebas.

c. Untuk menghindari terjadinya pembaruan hukum atau reformasi hukum yang tambal sulam, sehingga proses dan mekanisme perubahan atau penciptaan peraturan perundang-undangan yang baru sejalan dengan hukum dasarnya yaitu konstitusi. ${ }^{9}$

Dengan beberapa uraian tersebut di atas, maka perubahan UUD NRI 1945 yang dilakukan oleh MPR RI pada tahun 1999-2002 memang suatu keniscayaan untuk menyesuaikan dengan kondisi negara yang sedang terjadi berdasarkan kelemahan-kelemahan dalam penyelenggaraan negara yang sangat dirasakan sebelumnya, khususnya di era rezim Orde Baru di mana posisi

5 Moh. Kusnardi dan Harmaily Ibrahim, Pengantar Hukum Tata Negara Indonesia (Fakultas Hukum Universitas Indonesia 1988) 75.

6 Jimly Asshiddiqie, Konstitusi \& Konstitusionalisme Indonesia (Sekretariat Jenderal dan Kepaniteraan Mahkamah Konstitusi RI 2006) 36.

$7 \quad$ Ibid. 37.

8 Alwi Wahyudi, Hukum Tata Negara Indonesia dalam Perspektif Pancasila Pasca Reformasi (Pustaka Pelajar 2012) 251.

9 Sri Soemantri dan Moh. Mahfud MD., Op.Cit. 5. 
Presiden begitu kuat. Pada gilirannya dari kelemahan-kelemahan itulah yang menjadi sebab utama terjadinya pelanggaran HAM, pelanggaran prinsipprinsip negara hukum, pergeseran paham kedaulatan rakyat menjadi kediktatoran, executive heavy, serta tidak adanya check and balances yang terjadi, baik yang terjadi di masa Orde Lama maupun di masa rezim Orde Baru.

Berangkat dari uraian di atas maka masalah utama yang akan dikaji dalam tulisan ini sebagai konsekuensi dari dilakukannya perubahan terhadap UUD NRI 1945 adalah telah terjadi berbagai pergeseran kekuasaan di bidang legislatif-eksekutif-yudisial, serta terjadinya penguatan demokratisasi dalam penyelenggaraan negara. Sehubungan dengan itu maka dapat dirumuskan beberapa identifikasi masalah sebagai berikut. Pertama, apakah dengan adanya pergeseran kekuasaan pasca perubahan UUD 1945 telah menciptakan keseimbangan kekuasaan Presiden dalam hubungannya dengan lembaga negara yang lain? Kedua, apakah pergeseseran kekuasaan Presiden pasca perubahan UUD 1945 telah menyebabkan terjadinya penguatan kekuasaan DPR dalam sistem penyelenggaraan pemerintahan negara?

\section{PEMBAHASAN}

Perubahan UUD NRI 1945 yang dilakukan oleh MPR RI pada tahun 1999 sampai tahun 2002 mempunyai arti yang sangat strategis dalam kehidupan ketatanegaraan di Indonesia, khususnya dalam perkembangan kehidupan demokrasi di Indonesia. Arti penting bagi perkembangan kehidupan demokrasi itu, menurut Valina Singka Subekti, setidaknya dapat dilihat dari dua hal. Pertama, amandemen atau perubahan UUD NRI 1945 itu merupakan suatu hal yang tidak mungkin dilakukan di Indonesia sebelum era reformasi. Salah satu sikap politik yang diambil Orde Baru adalah mempersulit terjadinya amandemen UUD NRI 1945. UUD NRI 1945 dianggap sebagai dokumen yang sakral dan tidak boleh diganggu gugat, sehingga harus diterima sebagaimana adanya. Kedua, amandemen UUD NRI 1945 merupakan salah satu persyaratan penting bagi terselenggaranya demokratisasi secara lebih baik di Indonesia, karena demokratisasi akan mengalami kendala bila beberapa pasal dalam UUD NRI 1945 tidak diamandemen. ${ }^{10}$

Apabila melihat hasil dari keseluruhan perubahan yang dilakukan mulai dari perubahan pertama sampai dengan perubahan keempat pada tahun 1999-2002, maka dapat dikatakan perubahan terjadi di hampir keseluruhan materi muatan UUD NRI 1945, kecuali yang sama sekali luput dari sentuhan adalah bagian Pembukaan UUD NRI 1945. Dilihat dari itu dapat dikatakan telah terjadi perubahan besar dalam tatanan kehidupan berbangsa dan bernegara yang sudah dijalankan berdasarkan

10 Valina Singka Subekti, Op.Cit. xiii. 
ketentuan UUD NRI 1945 sebelum perubahan. Telah terjadi pergeseran di antara kekuasaan eksekutif, legislatif, dan legislatif, serta kemudian dilakukan redistribusi kekuasaan sedemikian rupa kepada bidang- bidang kekuasaan tersebut.

Dalam constitutional design yang dibuat oleh PAH III BP MPR terdapat beberapa kesepakatan dasar dalam rangka perubahan UUD NRI 1945, yaitu:

1. Tidak mengubah bagian Pembukaan UUD NRI 1945.

2. Tetap mempertahankan Negara Kesatuan Republik Indonesia.

3. Perubahan dilakukan dengan cara addendum.

4. Mempertegas sistem pemerintahan presidensial.

5. Penjelasan UUD NRI 1945 ditiadakan, hal-hal normatif dalam bagian penjelasan diangkat dalam pasal-pasal. ${ }^{11}$

Pasca Perubahan UUD NRI 1945 terdapat pergeseran kekuasaan diantara lembaga- lembaga negara yang ada. Menurut Moh. FajruI Falaak sebagaimana dikutif Gunawan A.Tauda, terdapat beberapa prinsip dasar dalam pendistribusian kekuasaan negara yang menyebabkan perubahan kelembagaan negara serta perubahan paradigma hukum dan ketatanegaraan, yaitu :

1. Secara mendasar UUD NRI 1945 meninggalkan prinsip supremasi parlemen (daulat parelemen) menuju kepada daulat konstitusi (negara hukum). Amandemen konstitusi mengganti supremasi parlemen menjadi supremasi konstitusi yang dijaga dan ditegakkan oleh Mahkamah Konstitusi. Dalam hal ini, UUD NRI 1945 bukan sekadar negara hukum, melainkan sebagai negara berkedaulatan rakyat yang pelaksanaannya berdasarkan konstitusi (constitutional democracy) dan sekaligus memerankan Mahkamah Konstitusi untuk menjaga dan menegakkan konstitusi Republik Indonesia.

2. Diterapkan prinsip pemisahan kekuasaan dan dilakukan redistribusi keuasaan serta pembentukan lembaga-lembaga negara baru. Dibutuhkan pemahaman ulang tentang keberadaan lembaga-lembaga negara dan tidak terbatas pemahaman yang berkembang selama Orde Baru. Pemisahan kekuasaan, redistribusi kekuasaan serta pembentukan lembagalembaga baru dirancang untuk menegaskan sistem presidensialisme.

3. Amandemen UUD NRI 1945 menegaskan independensi kekuasaan kehakiman serta mendudukan yudikatif sebagai pengawal konstitusi dengan menambah struktur baru kekuasaan kehakiman (Mahkamah Konsitusi), sehingga kekuasaa kehakiman berstruktur ganda.

11 Gunawan A. Tauda, Komisi Negara Independen: Eksistensi Independent Agencies Sebagai Kekuasaan Baru Dalam Sistem Ketatanegaraan (Genta Press 2012) 74. Dapat pula dilihat secara lengkap dalam Risalah Rapat Panitia Ad Hoc III BP MPR RI Tahun 1999. 
Tetapi, amandemen konstitusi untuk mempertegas sistem pemerintahan presidensial tidak tercapai penuh, karena UUD NRI 1945 justru menganut pola parlemnter dalam hal principal, yaitu legislasi. UUD NRI 1945 tidak memisahkan antara fungsi legislasi dari eksekutif.

4. Lembaga-lembaga negara pada dasarnya diletakkan pda kedudukan sejajar (nebengeornet) sekaligus dalam model hubungan check and balances, dan tidak lagi hirarkis pyramidal. Namun usaha menggambarkan model hubungan check and balances tidak mudah. Karena selain karena hubungan itu tidak sederhana, apalagi linier, konstitusi hasil amandemen masih baru sehingga hubungan antarlembaga masih mengalami perkembangan fluktuatif. ${ }^{12}$

Memperhatikan perubahan terhadap pasal-pasal dalam UUD NRI 1945 yang mengalami perubahan, maka dapat dikatakan bahwa pergeseran atau perubahan kekuasaan yang mencolok adalah pergeseran terhadap beberapa kekuasaan di bidang eksekutif atau kekuasaan yang ada hubungannya dengan kekuasaan presiden, atau perubahan-perubahan untuk melakukan pembatasan-pembatasan perbuatan presiden yang pada rezim sebelumnya banyak melakukan tindakan-tindakan, membuat kebijakankebijakan yang tidak sesuai dengan prinsip-prinsip negara hukum yang demokratis.

Terjadinya berbagai kebijakan dan tindakan pemerintah dalam hal ini presiden dalam penyelenggaraan pemerintahan negara yang tidak sesuai dengan prinsip-prinsip negara hukum yang demokratis, memang tidak terlepas dari besarnya kekuasaan presiden yang diatur dalam UUD NRI 1945. Menurut Bagir Manan ${ }^{13}$ struktur UUD NRI 1945 memberikan pengaturan yang dominan terhdap lembaga kepresidenan baik jumlah pasal maupun kekuasaannya. Tiga belas dari tiga puluh tujuh pasal UUD NRI 1945 mengatur langsung jabatan kepresidenan (Pasal 4 sampai dengan Pasal 15 dan Pasal 22). Selain itu terdapat pula ketentuan-ketentuan lain yang tidak mungkin terlepas dari Presiden, seperti ketentuan tentang APBN, ketentuan yang mengatur kewenangan MPR, DPR, DPA, BPK, undang-undang organik, dan lain sebagainya. UUD NRI 1945 juga memberikan kedudukan yang kuat kepada lembaga kepresidenan. Presiden adalah penyelenggara pemerintahan. Selain menjalankan kekuasaan eksekutif, Presiden juga menjalankan kekuasaan membentuk peraturan perundang-undangan, kekuasaan yang berkaitan dengan penegakkan hukum seperti pemberian grasi, amnesti, abolisi dan sebagainya.

12 Ibid. 74-76. Dapat pula dibaca dalam Moh. Fajrul Falaak, Redistribusi Kekuasaan Negara dan Model Hubungan Antar Lembaga Negara dalam UUD 1945 Pasca Amandemen (Laporan Penelitian WCRU-HTN Fakultas Hukum UGM 2009) 91. 
Pergeseran Kekuasaan Presiden Pasca Empat Kali Perubahan terhadap UUD NRI 1945

Pembatasan Masa jabatan Presiden

Setelah Perubahan UUD NRI 1945 secara tegas telah diatur pembatasan periodesasi masa jabatan pressieden. Sebelum Perubahan pertama UUD NRI 1945, masa jabatan presiden dan wakil presiden sama sekali tidak dibatasi. Pasal 7 UUD NRI 1945 sebelum perubahan menegaskan: "Presiden dan Wakil Presiden memegang jabatannya selama lima tahun, dan sesudahnya dapat dipilih kembali."

Pengaturan sebagaimana Pasal 7 UUD NRI 1945 di atas dipandang terlalu fleksibel dalam penafsirannya. Penafsiran yang umum dan diikuti pada masa kekuasaan pemerintahan Orde Baru adalah, masa jabatan presiden dapat dipilih kembali (berapa periode pun) apabila dikehendaki oleh Majelis Permusyawaratan Rakyat. Akibatnya penafsiran yang fleksibel tersebut kekuasaan Presiden Soeharto tidak terbendung sampai 7 periode, tepatnya selama 32 tahun sampai akhirnya ditumbangkan oleh kekuatan rakyat yang memaksanya untuk mengundurkan diri pada 21 Mei 1997.

Ketentuan Pasal 7 tersebut kemudian pada Perubahan Pertama UUD NRI 1945 diubah sehingga berbunyi: "Presiden dan Wakil Presiden memegang jabatan selama lima tahun dan sesudahnya dapat dipilih kembali dalam jabatan yang sama, hanya untuk satu kali masa jabatan." Menurut Ni'matul Huda, perubahan pasal ini dipandang sebagai langkah yang tepat untuk mengakhiri perdebatan tentang periodisasi jabatan Presiden dan Wakil Presiden. ${ }^{14}$

Pergeseran Kekuasaan Presiden dalam Bidang Legislasi

Berdasarkan Pasal 5 ayat (1) UUD NRI 1945, Presidena adalah pemegang kekuasaan pembantukan undangundang. Sedangkan ketentuan Pasal 20 ayat dan Pasal 21 ayat (1), Dewan Perwakilan Rakyat hanya berfungsi untuk membahas, menyetujui undangundang, dan hak inisiatif untuk memajukan rancangan undang-undang. Bahkan meskipun rancangan undangundang atas inisiatif Dewan Perwakilan Rakyat telah disetujui tetapi tidak disetujui oleh Presiden, maka rancangan tadi tidak boleh lagi dimajukan dalam persidangan Dewan Perwakilan Rakyat masa itu. Setelah Perubahan Pertama UUD NRI 1945, maka keuasaan pembentukan undang-undang atau fungsi legislasi tersebut dalam pasalpasal di atas telah bergeser menjadi kekekuasaan Dewan Perwakilan Rakyat sebagaimana dapat dilihat dalam Pasal 5 dan Pasal 20 UUD NRI 1945 pasca perubahan seperti dikutif secara lengkap di bawah ini.

\footnotetext{
13 Bagir Manan, Lembaga Kepresidenan (Pusat Studi Hukum Universitas Islam Indonesia dengan Gama Media 1999) 32.

14 Ni'matul Huda, Hukum Tata Negara Indonesia (PT. Raja Grafindo Persada 2012) 196.
} 
Pasal 5 UUD NRI 1945;

(1) Presiden berhak mengajukan rancangan undang-undang kepada Dewan Perwakilan Rakyat.

(2) Presiden menetapkan Peraturan Pemerintah untuk menjalankan undang-undang sebagaimana mestinya.

Pasal 20 UUD NRI 1945;

(1) Dewan Perwakilan Rakyat Memegang kekuasaan membentuk undang- undang.

(2) Setiap rancangan undang-undang dibahas oleh Dewan Perwakilan Rakyat dan Presiden untuk mendapat persetujuan bersama.

(3) Jika rancangan undang-undang itu tidak mendapat persetujuan bersama, rancangan undangundang itu tidak boleh diajukan lagi dalam persidangan Dewan Perwakilan Rakyat masa itu.

(4) Persidangan mengesahkan rancangan undang-undang yang telah disetujui bersama untuk menjadi undang-undang

(5) Dalam rancangan undang-undang yang telah disetujui bersama tersebut tidak disahkan oleh Presiden diam waktu tiga puluh hari semenjak rancangan undangundang tersebut disetujui, rancangan undang-undang tersebut sah menjadi undang-undang dan wajib diundangkan.
Berdasarkan perubahan ketentuan Pasal ayat 5 (1) dan Pasal 20 ayat (1) sebagaimana dikutif di atas dengan tegas telah terjadi pegeseran kekuasaan fungsi legislasi atau kekuasaan pembentukan undang-undang yang semula berdasarkan Pasal 5 ayat (1) UUD NRI 1945 sebelum perubahan sebagai kekuasaan Presiden, kemudian berdasarkan Pasal 20 ayat (1) pasca perubahan menjadi kekuasaan Dewan Perwakilan Rakyat, meskipun Presiden masih mempunyai hak untuk mengajukan rancangan undang-undang kepada Dewan Perwakilan Rakyat berdasarkan Pasal 5 ayat (1) pasca perubahan.

Perihal pergeseran kekuasaan pembentukan undang-undang ini, oleh saldi Isra, dinilai sebagai bagian dari furifikasi sistem pemerintahan presidensial, Pasal 20 yaitu (1) UUD NRI 1945 dapat dikatakan sebagai upaya menempatkan fungsi legislasi sebagai hak eksklusif lembaga legislatif, yaitu dengan menyatakan bahwa DPR memegang kekuasaan membentuk undang-undang. ${ }^{15}$ Sedangkan Jimly Asshiddiqie menyebutnya sebagai telah terjadi pergeseran kekuasaan substantif dalam kekuasaan legislatif atau kekuasaan pembentukan undangundang dari tangan presiden ke tangan DPR. ${ }^{16}$ Lebih jauh Jimly menulis:

15 Saldi Isra, Pergeseran Fungsi Legislasi: Menguatnya Model Legislasi Parlementer Dalam Sistem Presidensial Indonesia (RajaGrafindo Persada 2013) 210.

16 Jimly Asshiddiqie, Konsolidasi Naskah UUD 1945 Setelah Perubahan Keempat (Pusat Studi Hukum Tata Negara Universitas Indonesia, 2002) 25. 
Dengan adanya perubahan ini, jelas bahwa kekuasaan legislatif yang semula utamanya dipegang oleh presiden dengan persetujuan DPR dialihkan menjadi dipegang oleh DPR. Sedangkan presiden hanya dinyatakan berhak mengajukan rancangan undangundang, bukan sebagai pemegang kekuasaan legislatif yang utama. Perubahan ini biasanya yang biasa saya sebut sebagai pergeseran kekuasaan legislatif dari presiden ke DPR. ${ }^{17}$

Pengurangan Kekuasaan Presiden pada Aspek Diplomatik

Dalam hal pengangkatan dan penerimaan duta negara lain serta pemberian amnesti dan abolisi, tidak lagi menjadi hak prerogatif presiden, melainkan harus atas pertimbangan Dewan Perwakilan Rakyat. Perubahan atas Pasal 13 UUD NRI 1945 sehingga berbunyi sebagai berikut:

(1) Dalam hal mengangkat duta, Presiden memperhatikan pertimbangan Dewan Perwakilan Rakyat.

(2) Presiden Menerima penempatan duta negara lain dengan memperhatikan pertimbangan Dewan Perwakilan Rakyat.

Sebelum adanya amandemen terhadap Pasal 13 UUD NRI 1945 tersebut di atas memang kekuasaan untuk mengangkat dan menerima duta dan konsul dari negara lain menjadi hak prerogatif Presiden sebagai kepala negara sehingga Presiden menentukan sendiri tanpa harus terlebih dahulu memperhatikan pertimbangan dari Dewan Perwakilan Rakyat. Namun setelah adanya perubahan, Presiden harus memperhatikan pertimbangan dari Dewan Perwakilan Rakyat sebelum mengangkat duta dan konsul atau sewaktu akan menerima duta dan konsul dari negara lain.

Adanya keharusan untuk memperhatikan pertimbangan ini menurut Ni'matul Huda, sangat penting dalam rangka menjaga obyektivitas terhadap kemampuan dan kecakapan seseorang pada jabatan tersebut, dan karena ia akan menjadi duta dari seluruh rakyat Indonesia di negara lain di mana ia ditempatkan pada khususnya dan di mata internasional pada umumnya. ${ }^{18}$ Tetapi hal ini dapat juga ditafsirkan bahwa DPR telah ikut campur terlalu jauh dalam penyelenggaraan pemerintahan negara kepada hal yang sesungguhnya menjadi kekuasaan eksekutif.

Lebih lanjut, berdasarkan Pasal 11 ayat (2) UUD NRI 1945, Presiden dalam membuat perjanjian internasional yang menimbulkan akibat yang luas dan mendasar bagi kehidupan rakyat yang terkait dengan beban keuangan negara, dan atau mengharuskan perubahan atau pembentukan undang-undang harus dengan persetujuan Dewan Perwakilan Rakyat. Dengan ketentuan ini Presiden tidak dapat membuat perjanjian internasional tanpa meminta persetujuan kepada DPR.

Pengurangan Kekuasaan Presiden dalam Pemberian Grasi, Amnesti, Abolisi dan Rehabilitasi

\footnotetext{
${ }^{17}$ Ibid.

${ }^{18}$ Ni'matul Huda, Op.Cit. 197.
} 
Berdasarkan Pasal 14 UUD NRI 1945 sebelum perubahan, pemberian grasi, amnesti, abolisi, dan rehabiliasi menjadi kekuasaan mutlak Presiden. Perubahan pasal tersebut menjadi sebagai berikut:

(1) Presiden memberi grasi dan rehabilitasi dengan memperhatikan pertimbangan Mahkamah Agung.

(2) Presiden member amnesti dan abolisi dengan memperhatikan pertimbangan Dewan Perwakilan Rakyat.

Alasan kenapa Presiden perlu memperhatikan pertimbangan dari Mahkamah Agung dalam pemberian grasi dan rehabilitasi adalah karena grasi dan rehabilitasi itu adalah proses yudisial dan biasanya diberikan kepada orang yang sudah mengalami proses hukum dan lebih bersifat perorangan. Dengan demikian Mahkamah Agung sebagai lembaga peradilan tertinggi adalah lembaga negara yang paling tepat untuk memberikan pertimbangan kepada Presiden dalam hal itu karena grasi khususnya menyangkut putusan hakim, yang merupakan hasil pembahasan Dewan Perwakilan Rakyat bersama pemerintah sehingga pemberian gelar dan tanda jasa dan lainlaian yang akan diberikan Presiden adalah benar-benar didasarkan pertimbangan yang sangat objektif.

Sementara itu kenapa Dewan Perwakilan Rakyat yang diberi kewenangan untuk memberikan pertimbangan kepada Presiden dalam hal pemberian amnesti dan abolisi karena didasarkan pertimbangan politis, karena memang amnesti dan abolisi lebih bersifat proses politik.

Pergeseran Kekuasaan Presiden dalam Pemberian Tanda Gelar dan Tanda Jasa

Pasal 15 UUD NRI 1945 sebelum perubahan mengatur dengan singkat bahwa, "Presiden member grasi, amnesti, abolisi, dan rehabilitasi." Tetapi setelah Perubahan UUD NRI 1945, maka ketentuan Pasal 15 berubah menjadi: "Presiden memberi gelar, tanda jasa dan lain-lain tanda kehormatan yang diatur dengan undang-undang." Perubahan ketentuan dalam Pasal 15 ini dilakukan dengan pertimbangan agar Presiden dalam memberikan tanda gelar maupun tanda kehormatan kepada siapa pun harus berdasarkan pada undangundang.

Pengaruh DPR terhadap Presiden semakin menguat dengan adanya beberapa ketentuan sebagai berikut:

1. Hakim Agung tidak lagi diangkat sendiri oleh presiden melainkan diajukan oleh Komisi Yudisial untuk diminta persetujuan Dewan Perwakilan Rakyat untuk selanjutnya ditetapkan oleh presiden. (Perubahan Ketiga Pasal 24A ayat [3] UUD NRI 1945)

2. Angota Badan Pemeriksa Keuangan tidak lagi diangkat oleh presiden tetapi dipilih oleh Dewan Perwakilan Rakyat dengan memperhatikan Dewan Perwakilan Daerah dan diresmikan oleh presiden. (Perubahan Ketiga Pasal $23 \mathrm{~F}$ ayat [1] UUD NRI 1945).

3. Kekuasaan Presiden dalam pengangkatan Panglima TNI, Kapolri 
melalui persetujuan Dewan Perwakilan Rakyat (Tap MPR Nomor VII/MPR/2000 dan UUD NRI 1945).

Dari uraian-uraian yang dikemukakan di atas telah memberikan konsekuensi adanya pergeseran untuk perimbangan kekuasaan Presiden dalam hubungannya dengan kekuasaan DPR. Berdasarkan perubahan UUD NRI 1945 jelas-jelas banyak mengurangi kekuasaan yang dipegang oleh Presiden sebelumnya dan sebaliknya memberikan penguatan terhadap kekuasaan Dewan Perwakilan Rakyat (kekuasan legislatif).

Menurut Bagir Manan dan Susi Dwi Harijanti, perubahan UUD NRI 1945 tidak saja menyebabkan terjadinya pembatasan kekuasaan Presiden, akan tetapi lebih jauh Perubahan UUD NRI 1945 itu tidak taat asas, sebagaimana dikemukakan berikut :

Perubahan UUD 1945 tidak taat asas, mencampuradukkan antara hubungan legislatif dan eksekutif dalam sistem presidensil dengan sistem parlementer dengan memasukkan hak-hak pengawasan parlementer kepada Presiden. Bahkan UUD 1945 -Baru, dengan tegas mencantumkan fungsi pengawasan DPR (Pasal 20A). Memasukkan fungsi pengawasan dan berbagai hak parlemen kepada DPR, tidak sejalan dengan pengertian dan fungsi check and balances, dan bukan lagi sekadar mengurangi executive heavy; tetapi - seperti dikatakan terdahulu - merupakan bandul menuju legislative heavy yang lazim dalam sistem parlementer, dan itulah yang terjadi dalam tata kerja DPR sekarang ini. Bahkan, seperti disebutkan di atas, fungsi pengawasan lebih menonjol daripada fungsi legislatif. ${ }^{19}$

Lebih lanjut dikemukakan, bahwa perubahan UUD NRI 1945 telah menyebabkan adanya pembatasan kekuasaan Presiden yang mencakup pemindahkan kekuasaan membentuk undang-undang menjadi kekuasaan DPR, dan mengubah beberapa kekuasaan Presiden menjadi kekuasaan bersama DPR. Bahkan berbagai pembatasan terhadap kekuasaan Presiden berlanjut dalam undangundang seperti pengangkatan panglima TNI, Kapolri, dan lain- lain yang semula semata-mata merupakan keuasaan eksekutif, berubah menjadi kekuasaan bersama dengan DPR. Bahkan, DPR berwenang dalam hal- hal yang bersifat administrasi negara, seperti ikut serta dalam rincian pelaksanaan anggaran. Pembatasan kekuasaan Presiden di satu pihak, dan penguatan kekuasaan DPR di pihak lain, tidak hanya melampau paradigma check and balances, tetapi telah menjadi excessive karena DPR tidak hanya menjalankan fungsi legislatif, tetapi juga melaksanakan sejumlah fungsi administrasi negara. ${ }^{20}$

Kemudian dikemukakan oleh Bagir Manan dan Susi Dwi Harijanti, bahwa rumusan-rumusan perubahan UUD NRI 1945 di satu pihak telah menggeser paradigma lama, di pihak lain tidak sesuai dengan paradigma baru yang diharapkan yaitu keseimbangan antara kekuasaan Presiden dengan DPR. Paradigma lama sebagaimana tertuang

19 Bagir Manan dan Susi Dwi Harijanti, Memahami Konsitusi, Makna dan Aktualisasi (RajaGrafindo Persada 2014) 88-89.

20 Ibid. 
dalam Penjelasan sebenarnya mencerminkan salah satu aspek dari prinsip pemisahan kekuasaan antara Presiden dan DPR, yaitu Presiden tidak bertanggung jawab kepada DPR, tetapi Presiden juga tidak dapat membubarkan DPR. Dalam Praktik, khususnya di masa Orde Baru (juga di masa Orde Lama), Presiden berperan dominan dan DPR tidak mampu mengimbangi kekuasaan yang dominan ini. Perubahan UUD NRI 1945 hendak menyeimbangkan pendulum kekuasaan ini. Sayangnya yang terjadi bukan munculnya keseimbangan (balance of powers), melainkan DPR menjadi sangat kuat. ${ }^{21}$ Namun di sisi yang lain, perubahan terhadap ketentuan-ketentuan UUD NRI 1945, telah menempatkan juga posisi presiden semakin kuat karena dipilih langsung oleh rakyat. Presiden tidak mudah dijatuhkan atau dimakzulkan oleh MPR, meskipun terdapat perbedaan pandangan yang tajam dalam peneyelenggaraan pemerintahan negara dengan parlemen. Selama presiden tidak diputus telah melanggar hukum oleh Mahkamah Konstitusi, maka posisi presiden akan tetap aman. Selain itu presiden tidak lagi bertanggung jawab terhadap MPR karena presiden dipilih langsung oleh rakyat dan MPR tidak lagi sebagai lembaga tertinggi dan sebagai mandataris MPR sebagaimana ketentuan dalam UUD NRI 1945 sebelum perubahan.

Sebagaimana diketahui, menurut Penjelasan UUD NRI 1945, Presiden
Indonesia tunduk dan bertanggung jawab kepada MPR. Dengan demikian, secara yuridis formal MPR setiap saat dapat bersidang meminta pertanggungjawaban Presiden, dan itu berarti mempunyai konsekuensi setiap saat pula Presiden dapat diberhentikan oleh MPR. Dengan demikian, menurut Bagir Manan, pengertian "fixed executive" yang menjadi sistem presidensial seperti Amerika Serikat tidak terdapat dalam jabatan Presiden Republik Indonesia. Untuk hal ini dibuktikan dengan pemberhentian (penarikan mandat) Presiden Soekarno oleh MPRS pada tahun 1966. ${ }^{22}$ Demikian juga halnya dengan Presiden Abdurrahman Wahid berhenti dalam masa jabatannya karena dimakzulkan oleh MPR RI dalam Sidang Istimewa, karena dianggap melanggar UndangUndang Dasar dan Garis-Garis Besar Haluan Negara, sebagaimna dituangkan dalam Tap.MPR RI Nomor 11/MPR/2001, tanggal 23 Juli 2001.

Dengan Perubahan UUD NRI 1945 yang telah merubah sistem pemilihan presiden dari dipilih oleh MPR menjadi dipilih langsung oleh rakyat, sebagaimana dikemukakan di atas, telah menempatkan posisi Presiden dalam posisi yang relatif kuat. Dikatakan relatif kuat karena difihak lain dalam praktiknya, dalam menjalankan pemerintahan ternyata Presiden mendapat kontrol yang kuat akibat sistem multipartai yang dianut. 


\section{PENUTUP}

Berdasarkan keseluruhan uraian dalam tulisan ini maka dapat diambil beberapa kesimpulan sebagai berikut. Pertama, setelah dilakukan empat kali perubahan UUD NRI 1945 telah terjadi pergeseran dan redistribusi kekuasaan lembaga legislatif-eksekutif-yudisial. Kedua, telah terjadi pergeseran kekuasaan presiden dalam pembentukan undang-undang yang sebelumnya sebagai kekuasaan presiden beralih menjadi kekuasan DPR. Ketiga, kekuasaan presiden dalam pengangkatan anggota lembaga tinggi negara dan pejabat negara, setelah perubahan UUD NRI 1945 tidak lagi menjadi hak prerogatif presiden tetapi harus atas persetujuan/pertimbangan/ rekomendasi DPR, Mahkamah Agung, atau Komisi Yudisial.

Dengan adanya pergeseran kekuasaan terkait dengan hubungan antar kekuasaan legislatif-eksekutifyudisial maka menciptakan hubungan yang seimbang karena telah terdapat hubungan check and balances antara ketiga lembaga tinggi negara tersebut. Kondisi ini sejalan dengan prinsipprinsip demokrasi dan dengan demikian telah terjadi penguatan demokratisasi di Indonesia. Perubahan UUD NRI 1945 di satu pihak telah menyebabkan adanya pembatasan kekuasaan Presiden dan di pihak lain telah memberikan penguatan peran DPR yang lebih besar.

Supaya checks and balances tersebut sesuai koridor konstitusional yang diharapkan maka perlu kembali melakukan perubahan terhadap UUD
NRI 1945 untuk meluruskan kembali sistem presidensial yang dianut oleh UUD NRI 1945 yang pada perubahanperubahan yang lalu masih mencampuradukkan antara sistem presidensial dan sistem parlementer. Hal yang prinsip di sini adalah agar DPR tidak memasuki kepada hal-hal yang bersifat menjalankan fungsi administrasi negara yang sebenarnya adalah ranah kekuasaan Presiden.

\section{Daftar Bacaan}

Asshiddiqie, Jimly, Konstitusi \& Konstitusionalisme Indonesia (Sekretariat Jenderal dan Kepaniteraan Mahkamah Konstitusi RI 2006).

Asshiddiqie, Jimly, Konsolidasi Naskah UUD 1945 Setelah Perubahan Keempat (Pusat Studi Hukum Tata Negara Universitas Indonesia 2002).

Falaakh, Moh. Fajrul, Redistribusi Kekuasaan Negara dan Model Hubungan Antar Lembaga Negara dalam UUD 1945 Pasca Amandemen (Laporan Penelitian WCRU-HTN Fakultas Hukum UGM 2009).

Huda, Ni'matul, Hukum Tata Negara Indonesia (PT. Raja Grafindo Persada 2012).

Isra, Saldi, Pergeseran Fungsi Legislasi: Menguatnya Model Legislasi
Parlementer Dalam Sistem
Presidensial Indonesia(RajaGrafindo
Persada 2013). 
Kusnardi, Moh. dan Harmaily Ibrahim, Pengantar Hukum Tata Negara Indonesia (Fakultas Hukum Universitas Indonesia 1988).

Manan, Bagir, Lembaga Kepresidenan (Pusat Studi Hukum Universitas Islam Indonesia dengan Gama Media 1999).

Manan, Bagir dan Susi Dwi Harijanti, Memahami Konsitusi, Makna dan Aktualisasi (RajaGrafindo Persada 2014).

Soemantri, Sri, Prosedur dan Sistem Perubahan Konstitusi (Alumni 2006).

Soemantri, Sri, dan Moh.Mahfud MD, Amandemen UUD 1945 Antar Teks dan Konteks Dalam Negara Yang Sedang Berubah (Sinar Grafika, 2000).

Subekti, Valina Singka, Menyusun Konstitusi Transisi: Pergulatan Kepentingan dan Pemikiran dalam Proses Perubahan UUD 1945 (Rajawali Pers 2008).

Sulardi, Reformasi Hukum-Rekonstruksi Kedaulatan Rakyat dalam Membangun Demokrasi (In-TRANS Publishing 2009).

Tauda, Gunawan A., Komisi Negara Independen: Eksistensi Independent Agencies Sebagai Kekuasaan Baru Dalam Sistem Ketatanegaraan (Genta Press 2012).

Wahyudi, Alwi, Hukum Tata Negara Indonesia Dalam Perspektif Pancasila Pasca Reformasi (Pustaka Pelajar 2012). 